\title{
Tropical Grain Legumes as Important Human FoOds ${ }^{1}$
}

\author{
U. SiNGH ${ }^{2}$ AND B. SingH
}

\begin{abstract}
Singh, Umaid (International Crops Research Institute for the Semi-Arid Tropics, P.O. Patancheru, 502 324. Andhra Pradesh, India), and Bharat Singh (Department of Food Science, Alabama A\&M University. Normal, AL 35762). Tropical. Grain LEgumes as IMPORTANT HuMan FoOds. Economic Botany 46(3):310-321. 1992. Grain legumes continue to occupy an important place in human nutrition as sources of protein, vitamins and minerals. From a nutritional point of view chickpea, pigeonpea, mung bean, urd bean, cowpea, lentil. soybean and peanut are the important grain legumes for the millions of people in semi-arid and tropical regions of many Asian and African countries. These legumes are used in various food forms after suitable processing depending on the regions of their production and consumption. Such aspects as production and consumption, processing and food uses, chemical composition, and effects of processing on the nutritive value of these legumes are the important topics of this paper. To enhance their utilization, new potential and diversified food uses have been highlighted. Future research needs and priority areas are listed to improve their utilization and nutritional quality.
\end{abstract}

Key Words: food grain legumes, protein sources, pulses.

Cereal grains and grain legumes provide the major sources of calories and proteins for a large proportion of the world's population (NAS 1975). In terms of quantity, cereals occupy the first place as sources of calories and proteins and grain legumes are the next (Salunkhe 1982). About 80\% of the proteins consumed by the humans in developing countries are supplied by plants, a statistic which has remained static during the past two decades as shown in Table 1. Protein caloriemalnutrition (PCM) is believed to be the primary nutritional problem in most developing countries of the world (Olson 1975). Legumes are rich sources of protein and the essential amino acid, lysine, but are usually deficient in sulphur-containing amino acids, methionine and cystine. On the other hand, cereal-grain contains lower amounts of proteins which are deficient in lysine but have adequate amounts of sulphur amino acids (Eggum and Beame 1983). It is often, therefore, emphasized that legume seed grain proteins are the natural supplement to cereal grain protein in producing an overall essential amino acid balance. Also, there is a growing recognition that

' Received 10 July 1990; accepted 20 May 1992. Submitted as Journal Article No. 1277 by the International Crops Research Institute for the Semi-Arid Tropics.

'Reprint requests. legumes and their products are good sources of vitamins and minerals. Although grain legumes contain various antinutritional factors which impair their nutritional quality, these factors may be removed by processing (Liener 1979; Singh, U. 1988).

Pulses are cheaper sources of proteins when compared to animal proteins in developing countries (Singh and Jambunathan 1991). There are also well recognized shortcomings in consuming animal proteins in the developing countrics such as unhygienic processing and storage and consequent microbial contamination. In addition, pulses have been reported to reduce the levels of cholesterol and blood glucose (Soni et al. 1982). Apparently, pulses are and will continue to be important sources of proteins in the diets of people living in the developing countries.

This paper summarizes the available information on production, processing and food uses, chemical composition and the effect of processing on the nutritional value of some important grain legumes as listed in Table 2.

\section{Production and Consumption}

Generally, the areas of production are the areas of wide consumption of food crops. By and large, this is true for grain legumes excepting soybean of which a large proportion enters the interna- 
TABLE 1. SUPPLY OF PROTEIN FROM PLANT AND ANIMAL PRODUCTS IN THE WORLD.

\begin{tabular}{|c|c|c|c|c|c|c|c|c|}
\hline \multirow[b]{4}{*}{ Ycar } & \multicolumn{8}{|c|}{ g/caput/day } \\
\hline & \multicolumn{4}{|c|}{ Plant protein } & \multicolumn{4}{|c|}{ Animal protein } \\
\hline & \multicolumn{2}{|c|}{$1961-1963$} & \multicolumn{2}{|c|}{$1984-1986$} & \multicolumn{2}{|c|}{$1961-1963$} & \multicolumn{2}{|c|}{$1984-1986$} \\
\hline & $a$ & $\mathrm{~b}$ & a & b & a & b & a & b \\
\hline World & 42.8 & 68.3 & 46.2 & 65.7 & 19.8 & 31.7 & 21.1 & 34.3 \\
\hline Developed countries & 46.4 & 51.0 & 43.1 & 42.6 & 44.6 & 49.0 & 58.1 & 57.4 \\
\hline Developing countries & 41.1 & 83.2 & 47.3 & 78.8 & 8.3 & 16.8 & 12.7 & 21.2 \\
\hline
\end{tabular}

Source: FAO Production Year Book 1988.

a. Protein supply ( $\mathrm{g} / \mathrm{capu} / \mathrm{day}$ ).

b. Calculated as percentages of total supply of protein.

tional market in both raw and processed forms. Major areas of production and consumption of some important grain legumes are summarized in Table 2. As a matter of convenience such grain legumes as chickpea, pigeonpea, mung bean, urd bean, and lentils are commonly referred to as pulses in the Indian subcontinent and hence the term is used interchangeably. Approximately $75 \%$ of the total world yield of pulses is produced in the developing countries. India accounts for about $70 \%$ and $85 \%$ of the total world production of chickpea and pigeonpea, respectively (Singh, U. 1987). The Indian subcontinent (India, Pakistan, and Bangladesh) produces about $38 \%$ of the world production of lentil (Khan et al. 1987). Canada is the fourth largest producer and second largest exporter of lentils in the world (Bhatty 1988). Asia produces nearly $55 \%$ of the world pulse crops and India accounts for about $50 \%$ of the total production of pulses in Asia (Table 3). However, Africa accounts for nearly $12 \%$ of the total production of pulses in the world. Interestingly, it is observed that pulse production has increased during recent years in Africa as shown in Table 3. The production of pulse crops generally and in particular those of tropical countries has increased very slowly over the past decade in comparison with soybean (Table 3 ). Pulse crops are largely consumed in the regions where they are produced and hence contribute very little to international trade.

Chickpea and pigeonpea are very important

TABLE 2. AREAS OF PRODUCTION AND CONSUMPTION OF SOME IMPORTANT TROPICAL GRAIN LEGUMES IN THE WORLD.

\begin{tabular}{llc}
\hline \hline \multicolumn{1}{c}{ Common name } & \multicolumn{1}{c}{ Latin name } & \multicolumn{1}{c}{ Areas } \\
\hline $\begin{array}{l}\text { Chickpea, Bengal gram, } \\
\text { Garbanzo bean }\end{array}$ & Cicer arietinum & $\begin{array}{c}\text { Grown in tropics and subtropics in Asia and Afri- } \\
\text { ca. Widely cultivated in India, Turkey, and Pa- } \\
\text { kistan. Also grown in Mediterranean countries } \\
\text { and South America. }\end{array}$ \\
Pigeonpea, Red gram, Arhar & Cajanus cajan & $\begin{array}{c}\text { Grown in tropics and subtropics in Asia and Afri- } \\
\text { ca. Widely cultivated in India. Also grown in } \\
\text { South Pacific islands and Australia. }\end{array}$ \\
Mung bean, Green gram & Vigna radiata & $\begin{array}{c}\text { South and Southeast Asia, and some East African } \\
\text { countries. Popular in India, China, Thailand } \\
\text { and the Philippines. }\end{array}$ \\
Urd bean, Black gram & Vigna mungo & $\begin{array}{c}\text { Tropical South Asia, widely grown in India and } \\
\text { Pakistan. }\end{array}$ \\
Cowpea & Vigna unguiculata & $\begin{array}{c}\text { Tropical Asia, and Africa. Also, southern Europe } \\
\text { and the Americas. }\end{array}$ \\
Lentil & Lens esculenta & $\begin{array}{c}\text { Near East, India, Africa, Central and South Ameri- } \\
\text { ca. }\end{array}$ \\
Soybean & Glycine max & $\begin{array}{c}\text { South and East Asia, particularly China, Japan, } \\
\text { and USA. }\end{array}$ \\
Peanut & Arachis hypogaeae & $\begin{array}{c}\text { Grown in tropical and subtropical region, Central } \\
\text { and South America. }\end{array}$
\end{tabular}


TABLE 3. WORLD PRODUCTION (MILLION MT) OF SOME IMPORTANT GRAIN LEGUMES.

\begin{tabular}{|c|c|c|c|c|c|c|}
\hline \multirow[b]{2}{*}{ Constituent/country } & \multicolumn{2}{|c|}{ Pulses } & \multicolumn{2}{|c|}{ Soybean } & \multicolumn{2}{|c|}{ Peanut (in shell) } \\
\hline & $1979-1981$ & 1988 & 1979 & 1988 & $1979-1981$ & 1988 \\
\hline World & 40.81 & 54.65 & 85.98 & 92.33 & 18.55 & 22.75 \\
\hline Africa & 5.36 & 6.87 & 0.33 & 0.47 & 4.53 & 4.61 \\
\hline N C America & 3.38 & 3.46 & 56.10 & 43.45 & 1.74 & 1.97 \\
\hline South America & 3.01 & 3.86 & 18.01 & 29.76 & 0.98 & 0.71 \\
\hline Asia & 21.26 & 23.24 & 10.34 & 15.44 & 11.22 & 15.38 \\
\hline Europe & 2.54 & 6.91 & 0.62 & 2.36 & 0.02 & 0.03 \\
\hline Oceania & 0.21 & 1.59 & 0.09 & 0.07 & 0.05 & 0.05 \\
\hline India* & 10.51 & 11.23 & 0.36 & 1.35 & 6.00 & 7.30 \\
\hline China* & 6.65 & 5.68 & 8.27 & 10.92 & 3.50 & 5.86 \\
\hline
\end{tabular}

Source: FAO Production Year Book 1988.

- Values for India and China are also included under Asia.

pulse crops in India as they occupy nearly $45 \%$ of the total pulse area and contribute about $60 \%$ of the total pulse production in the country (Singh, U. 1987). However, chickpea and pigeonpea provide only $7 \%$ and $2 \%$, respectively, of the total production of the grain legumes in the world (Hulse 1991). Recently it has been observed that during the last decade legume production in the Asia region increased by $1.7 \%$ per year and this resulted in a decline per capita availability of $2 \%$ per year due to increase in population (Singh, $R$. B. 1984). Further, the figures of daily per capita consumption of legumes are reported to be $43 \mathrm{~g}$ for Pakistan, $35.7 \mathrm{~g}$ for India, $23 \mathrm{~g}$ for Indonesia, $42 \mathrm{~g}$ for China, $30-40 \mathrm{~g}$ for Africa, 25-50 $\mathrm{g}$ for the Middle East and South America and $16 \mathrm{~g}$ for Europe (Khan 1987). In India, the production of pulses in the period 1979-1988 has remained stagnant around nearly eleven million tons ( $\mathrm{Ta}$ ble 3). Even though increasing attention has been paid to grain legume crops in India, it has shown little impact on improving production or productivity in these legumes (FAO 1988).

By far the most important grain legumes under cultivation are the soybean and peanut which represent roughly $50 \%$ and $16 \%$, respectively of total world production of grain legumes (Hulse 1991). Nearly two thirds of the world's soybeans are grown in the United States (Table 3), while Brazil and China are estimated to be responsible for 15 and 10\%, respectively (FAO 1988). Soybean production has shown a remarkable increase in the world, a $50 \%$ increase has been recorded during the past decade. Furthermore, the developing countries' share of the world soybean crops is nearly $40 \%$, of which more than half comes from South America. In recent years, many countries in Asia and Africa have focused on the soybean as a potential crop. As a result, some increase in soybean production has been recorded in these countries (Table 3 ).

The peanut is a native of South America and is grown in about 80 countries in the world. World peanut production is increasing and it has reached a new high of about 23 million tons (in-shell) according to recent FAO estimates (Table 3). The cultivated peanut is the most important oilseed in the developing world and a valuable source of protein for human and animal nutrition. About $80 \%$ of world production is from developing countries and approximately $67 \%$ from the semiarid tropics. India is the largest producer of peanuts in the world, averaging about seven million tons annually (FAO 1988). China followed by the United States and countries in Africa are next in order of importance so far as peanut production is concerned. India and China produce almost $60 \%$ of the world's peanut crop (Table 3 ). Most of the peanuts produced in India are consumed within the country whereas a considerable amount of China's production is exported.

\section{Processing and Food Uses}

Dry whole-seeds of these legumes possess a fibrous seed coat, or testa ("husk" or "skin"). The seed coat is often indigestible and sometimes causes a bitter taste. Therefore, most of these legumes are consumed after dehusking. Before use as human food, legumes receive two major traditional treatments: 1) dehulling which converts whole seed into dhal, i.e., decorticated dry split cotyledons; and this is sometimes referred to as a primary process; and 2) cooking, a sec- 
ondary process, which often includes such treatments as soaking, boiling, frying, roasting, fermentation, germination, etc., depending on the type of food and the region of consumption. All these processes improve appearance, texture, cooking quality and palatability.

\section{Dehulling Processes}

Not only does dehulling improve palatability and digestibility of legume seeds, it also remarkably reduces their cooking time. In India, dehulling of dry seeds of pigeonpea, chickpea, urd bean and mung bean is very important because the major portion of these legumes is consumed in the form of dhal (Singh, U. 1987). Several methods exist for the preparation of dhal. Largescale dehulling using commercial dhal mills and small-scale dehulling, usually carried out manually by quern and hand-pounding, are the common methods of dehulling of these legumes in India, Pakistan and some African countries (Dolvo et al. 1975).

Proper dehulling of legumes for human nutrition essentially relates to efficient separation of the seed coat from the cotyledons. Household dehulling of legumes is often laborious, time consuming and inefficient. Dhal yields obtained by household dehulling are noticeably lower than those obtained by large-scale dehulling from commercial dhal mills (Singh and Jambunathan 1981). Of late, efforts have been made to develop laboratory methods of dehulling and to identify genotypes with improved dhal yield (Ehiwe and Reichert 1987). These workers also observed significant differences in dehulling characteristics of cowpea, pigeonpea and mung bean and noticed that in mung bean dehulling quality was generally poor. Most common methods of dehulling of legumes remove the germ along with the husk and thereby incur loss of thiamine, an important dietary vitamin (Aykroyd and Doughty 1964: 43). Since dehulling results in considerable losses of nutritionally important dietary constituents, it is important to develop suitable methods of dehulling to reduce these processing losses (Singh, Rao, Seetha, and Jambunathan 1989).

In Southeast Asia and some countries of Africa, dehulling of soaked and boiled soybean and cowpea is commonly preferred for preparation of various food items (Siegel and Fawcett 1976). Soaking followed by boiling as a pretreatment to dehulling facilitates removal of the husk. By and large, this wet-method of dehulling is very com- mon in some Mediterranean countries for lentils and chickpeas (Hawtin 1981) and in some Latin American and African countries for the cowpea (Dolvo et al. 1975).

\section{COOKING AND FOOD USES}

For various food uses of grain legumes, cooking is of vital importance. Further, several legume-based food items are prepared in traditional ways.

\section{Chickpea}

In several countries, traditional ways of using chickpea include soaking, germination, boiling, frying and roasting. Dhal and food items prepared from besan (dhal flour) are the major forms of chickpea consumption in India, Pakistan and Bangladesh. "Phutna" (roasted grains), "pakora" (oil fried), "kadi" (boiled in buttermilk), "roti" (chickpea flour in combination with wheat flour), "dhokla" (fermented product) and "satu" (roasted chickpea flour with cereal flours) are other common food preparations in India (Jambunathan and Singh 1990). It is also used to make several sweets and snack items. Raw and roasted green seeds of chickpea are also consumed in India, Turkey, Ethiopia and Pakistan. Chickpea is used in the form of whole seed in Australia, Europe, USA, and West Asia, North Africa and Latin America. In these countries, chickpea soup and salad are also prepared. Some important chickpea recipes have been compiled in the chickpea cookbook (Hawtin 1981). In Turkey which is the second largest chickpea growing country, chickpea is consumed in the form of soup, meals, desserts, and baby foods. Kabulitype chickpeas are often detexturized (made softer) and used in the preparation of snacks, such as quadami stamboulich, quadami safra, or quadami bisukar in the Mediterranean region (Williams and Singh 1988).

\section{Pigeonpea}

For use as human food, pigeon pea is consumed in various forms. Immature green tender pods are cooked and eaten in some Southeast Asian countries. Green and immature seeds are also used fresh as a vegetable in India (Faris et al. 1987). Processed and canned green pigeon pea seeds are used fresh as a vegetable in some $\mathrm{Ca}$ ribbean and Latin American countries. In India, mature dry whole seeds are mostly consumed 
after dehusking largely in the form of dhal whereas in some African countries whole seeds are consumed after boiling. Pigeonpea "tempeh," a fermented product, is becoming a popular food in Indonesia where tempeh is traditionally prepared from soybean. It has been suggested that pigeonpea has a good potential as a soybean substitute for tempeh preparation in Indonesia. Some steamed dishes based on pigeonpea are also prepared in some Asian and African countries. Pigeonpea has also been observed as a potential source of starch for noodle preparation (Singh, Voraputhaporn, Rao, and Jambunathan 1989). Freshly sprouted pigeonpeas and germinated and malted flours have yet to become acceptable food products of pigeonpea in Southeast Asia and the Indian sub-continent.

\section{Mung Bean}

About $85 \%$ of mung bean production is consumed in several countries of Asia (Bhumiratana 1978). A variety of food products is prepared from mung bean. In India and Pakistan, it is consumed in the form of dhal and whole as well as after boiling and frying. Traditionally, mung beans are cooked either as whole seed or sprouted as a vegetable dish. Mung bean sprouts are very popular and a common vegetable in China as well as in many other Asian countries (Chen et al. 1975; Chang 1978), India, and the United States (Rachie and Roberts 1974). They are sometimes used in soup or with sugar as a snack or a dessert. In some Southeast Asian countries, mung beans are boiled and used with rice soup during the summer as a protein supplement for several baby foods. Mung bean has also occupied an important place in noodle preparation and its starch has been reported as the best raw material for transparent starch noodles. The noodles prepared from the isolated starch fraction of mung bean have been found to be very acceptable by the consumer and with respect to their physicochemical properties (Singh, Voraputhaporn, Rao, and Jambunathan 1989). Starch fraction and protein isolates of mung beans can be prepared from the same seed material and used in different food preparations (Bhumiratana 1978). Porridge-type weaning foods can be prepared from boiled, mashed, and sieved mung beans with added cereals and sugar. MCM weaning food which is a blend of 80 parts mung bean flour, 15 parts coconut flour and 5 parts skimmed milk powder is quite popular in several Southeast
Asian countries, particularly the Philippines and Thailand (Payumo 1978).

\section{Cowpea}

The cowpea is indigenous to Africa and consumed in various forms in different African countries. The cowpea is probably the most popular grain legume in West Africa (Dolvo et al. 1975). Fermented foods based on corn-cowpea flour blends are becoming popular as protein supplements for infant and weaning foods in $\mathrm{Ni}$ geria (Akobundu and Hoskins 1987). Cowpeas are consumed in three basic forms in African countries (Rachie and Roberts 1974). First and most frequently, they are cooked together with vegetables, spices and other ingredients to make a thick soup or gruel which is caten in association with the basic staple such as preparations of cassava, yams, plantain, or cereals. Second, they are deep-fried as cakes ("akara" balls) prepared from a decorticated flour, and third as steamed products prepared from decorticated flour. Locally named, "ewa," "alpa," and akara are the common food preparations of cowpea in Nigeria, whereas "koose" is a popular common food in Ghana. In India, they are used in the form of young pods and dry seeds as well. Most are used as whole dry seeds which are boiled to tenderness and fried for curry preparation (Singh, U. 1987). A variety of foods ranging from main dishes and snack foods to desserts are prepared from cowpeas in Thailand (Ngarmsak 1989).

\section{Lentil}

Lentil is used primarily as human food. It is consumed in the form of the whole seed and dhal. Although low in methionine and cystine, lentil is still an excellent source of protein and essential amino acids when used to complement cereal protein, particularly wheat, with which it is most often eaten in developing countries (Bhatty 1988). In some European countries and the Americas, some lentils are used in soup. Soup made from the lentil by a commercial processor was well liked, being large-seeded and of pleasing appearance (Bhatty 1988). However, the potential for consumption of canned lentils appears to be limited. Lentil has been milled and air-separated into starch and protein fractions for incorporation into food and feed products and for industrial utilization, particularly starch (Tylor et al. 1981). 


\section{Soybean}

Soybean food items are very popular in Asia and a large amount of soybeans is consumed traditionally after processing (Saio and Watanbe 1984). "Tofu," "miso," "natto," and "kinako" are popular foods of soybean in Japan, whereas tempeh, a fermented product of soybean, is popular in Indonesia and China. Among foods derived from soybean, tofu is very popular in Thailand and other Southeast Asian countries (Saio and Watanabe 1984).

Fermented food products made from soybean form a significant portion of the diets of the Asian populations and the consumer acceptability of such products is specific to countries or regions on account of their characteristic flavor (Ebine 1986). Miso, a commonly used fermented food in Japan, China and other parts of the Orient is a cooked paste made from soybean and cereals, mostly rice. Traditionally, Indonesian tempeh is prepared from cooked soybeans by a fermentation process using the mold Rhizopus oligosporus. "Natto" is another popular fermented soybean food product which is popular in specific regions of Japan. "Sufu" is a popular fermented food in China. Sufu making involves the production of soybean protein curd (tofu) and its subsequent fermentation using species of mold. Besides fermented foods, soybean is popularly consumed in the form of soy-milk prepared by a variety of methods in different parts of the world. The milk-like suspension prepared by wet grinding and filtration of soaked soybean has been a popular beverage of millions in several countries of Asia.

\section{Peanut}

In addition to being a good source of edible oil in several developing countries, several food uses of peanut are known (Singh and Singh 1991). Peanut has some very important advantages over the other major oil seeds. It can be prepared in many food forms with only simple roasting and grinding. Lusas (1979) reported that about $60 \%$ of the peanuts harvested outside the United States are crushed while about $70 \%$ of the United States crop is used directly for food purposes. He further reported that boiled fresh peanuts, roasted peanuts, peanut candies, and peanut butter are important food uses in the United States. Peanut butter is one of the most popular peanut products in several countries. The basic steps of manu- facturing peanut butter include cleaning of shelled peanuts, roasting, blanching, blending of ingredients, grinding, cooling and packaging. Peanuts are used extensively in roasted peanut butter candies and in ice cream. About $52 \%$ of the domestic edible peanut crop is used for peanut butter spreads, $23 \%$ for salted peanuts and $21 \%$ for confectionary in the United States (Evans 1982).

Peanut hull is used to increase dietary fiber in commercially baked wheat bread (Collins et al. 1982). Peanut could be used as a protein supplement in low-cost Nigerian foods such as "chinchin," "puff-puff," and "akara" and all these peanut supplemented foods were rated high in several food studies (Reber et al. 1983). Whiteskin peanut flours are used in protein fortification of breads, cookies and muffins (Ory and Conkerton 1983). Results of a recent survey in some African countries indicate that peanuts are commonly used as roasted, ground (or paste), peanut oil, boiled or raw; the most commonly utilized form is the roasted peanut followed by ground peanut paste (Singh, B. 1986). To improve their nutritional quality, sorghum based food products "kisra" and "toe" and the cassava-based product "gari" could be fortified with peanuts. Peanut can also be used in the form of "kuli-kuli," an indigenous Nigerian peanut-based snacking food, and a yogurt-like product called "mish" in some African countries. In a recent report, B. Singh (1991) has enumerated several cereal-based foods using groundnut and other legumes.

\section{Nutritive Value}

Like other food crops, the chemical composition of these legumes is also the first approximation of their nutritive value. The literature on the nutritional composition and grain quality of food legumes is voluminous but scattered. In general, legumes contain 18 to $25 \%$ protein, about double that of the cereals. Carbohydrates and proteins are the principal constituents of most grain legumes (Table 4).

Chickpea contains the highest amount of carbohydrates and the lowest amount of protein. However, the protein content of chickpea ranges between 12.6 and $30.5 \%$, showing a large variation due to environment and cultivars (Singh, U. 1985). Protein content of mung bean, urd bean, cowpea and lentil is comparable but considerably higher than chickpea and pigeonpea (Table 4). The protein content of dry soybean seed varies from 37 to $50 \%$, but it is usually in 
TABle 4. Chemical COMPOSITION OF SEED LEgUMES. ${ }^{a}$

\begin{tabular}{|c|c|c|c|c|c|c|c|c|}
\hline & Protein & Fat & $\begin{array}{c}\text { Carbo- } \\
\text { hydrates }\end{array}$ & Fiber & Calcium & Iron & Thiamine & $\begin{array}{l}\text { Ribo- } \\
\text { flavin }\end{array}$ \\
\hline & \multicolumn{4}{|c|}{$\mathrm{g} 100 \mathrm{~g}^{-1}$} & \multicolumn{4}{|c|}{$\mathrm{mg} 100 \mathrm{~g}^{-1}$} \\
\hline Chickpea & 17.1 & 5.3 & 60.9 & 3.9 & 202 & 10.2 & 0.30 & 0.15 \\
\hline Pigeonpea $^{b}$ & 19.3 & 2.0 & 62.7 & 6.4 & 132 & 9.8 & - & - \\
\hline Mung bean & 24.0 & 1.3 & 56.7 & 4.1 & 124 & 7.3 & 0.47 & 0.28 \\
\hline Urd bean ${ }^{c}$ & 23.7 & 2.8 & 66.2 & 4.0 & 204 & 6.7 & - & - \\
\hline Cowpea & 24.1 & 1.0 & 54.5 & 3.8 & 77 & 5.9 & 0.51 & 0.20 \\
\hline Lentil & 25.1 & 0.7 & 59.0 & 0.7 & 69 & 4.8 & 0.45 & 0.20 \\
\hline Soybean & 43.2 & 19.5 & 20.9 & 3.7 & 240 & 11.5 & 0.73 & 0.39 \\
\hline Peanut & 25.0 & 40.1 & 26.1 & 3.1 & 90 & 2.8 & 0.90 & 0.13 \\
\hline
\end{tabular}

a Source: Gopalan et al. (1985).

b Source: El Hardallou et al. (1980) for seed sample.

c Source: Shobhana et al. (1976) for seed sample.

the region of $40 \%$. Outer layers of cotyledons are richer in protein content indicating that protein is unevenly distributed in the cotyledons and is liable to losses due to processing (Singh, Rao, Seetha, and Jambunathan 1989). Soybean and peanut contain the highest amount of oil, followed by chickpea, which contributes a considerable amount of fat to the human diet. Chickpea fat content ranges between 3.8 and $10.2 \%$ (Singh, U. 1985).

Tropical grain legumes are also considered to be important sources of minerals and vitamins. Of the various minerals, calcium and iron are very important, particularly in the diets of lactating women and school children. The cotyledons of chickpea, pigeonpea, mung bean, and urd bean contain significantly lower amounts of calcium than those of their whole seeds suggesting that whole seed of these legumes could be a good source of calcium (Rao and Deosthale 1981). Further, these legumes as whole grain and cotyledons appeared to be significant contributors to the daily requirements of magnesium, manganese and copper in the diet. Cotyledons being the major and fairly balanced component account for almost the entire food value of the whole seed. Chickpea seeds are richer sources of iron as compared to other legumes. Some chickpea genotypes contain $14.0 \mathrm{mg} / 100 \mathrm{~g}$ iron, possibly the highest of all legumes (El Hardallou et al. 1980). Large variations in the levels of minerals and trace elements of genotypes of different legumes have been reported (Rao and Deosthale 1981). As shown in Table 4, these legumes also show a large variation in the contents of calcium, iron, thiamine, and riboflavin, the important dietary constituents from a nutritional point of view.

\section{EFFECT OF PROCESSING ON THE Nutritive VALUE}

The beneficial effects of processing on the nutritive value of food legumes are envisaged in two areas: a) improved bioavailability of nutrients and b) partial or complete removal of antinutritional and toxic compounds. For use as foods, most grain legumes undergo three major processes: 1) soaking and germination, 2) fermentation, and 3) cooking-heat treatment. Effects of processing practices on the nutritive value are described below.

\section{Soaking and Germination}

Soaking and germination improves the starch digestibility in legumes (Jyothi and Reddy 1980). These workers reported that digestibility was highest in cowpea, followed by mung bean, chickpea, urd bean and pigeonpea in that order. This trend was also observed in germinated and cooked samples of these legumes.

The oligosaccharides which interfere with carbohydrate digestibility and produce flatulence are remarkably reduced by soaking and germination. Germination decreased the oligosaccharide contents of chickpea, pigeonpea, mung bean and urd bean (Rao and Belavady 1978). During germination, the seeds undergo marked metabolic changes. As a result of enzymatic degradation, a complete disappearance of verbascose, stachyose and raffinose after $48 \mathrm{hr}$ of germination of urd bean was reported by Reddy and Salunkhe (1980). Germination followed by cooking brought about $60 \%$ reduction in the levels of total oligosaccharides in chickpea and $70 \%$ in pigeonpea (Iyengar and Kulkarani 1977). Germinated chickpea and pigeonpea produced less flatus than unger- 
minated as measured in albino rats (Savitri and Desikachar 1985). However, germination did not bring about appreciable changes in the trypsin inhibitors of chickpea (Khaleque et al. 1985) and mung bean (Noor et al. 1980).

Soaking followed by germination considerably reduced the trypsin inhibitor activity in pigeon pea and lentil. Wilson and Tan-Wilson (1983) reported a rapid modification of trypsin inhibitor in mung bean as a result of degradation of trypsin inhibitor by proteinases in germinating mung bean. Germination also causes an increase in a number of vitamins. Ascorbic acid content of soybeans and mung beans increased from 4 to 20 fold as a result of germination (Chen et al. 1975). On a dry weight basis, riboflavin content in mung bean and soybean increased to 2.5 times the original as a result of germination (Kylen and McCready 1975). These workers also found an increase in niacin and ascorbic acid during germination of soybean, mung bean and lentils but the effect was more pronounced in mung beans. The protein-phytic complexes are more responsible for the reduced bioavailability of minerals. Germination can reduce or eliminate appreciable amounts of phytic acid of legumes and hence improve mineral bioavailability (Salunkhe 1982). According to Rao and Deosthale (1982), nearly $50 \%$ of polyphenolic compounds were lost in chickpea, pigeonpea, mung bean, and urd bean as a result of overnight soaking in water and when germination was further continued for 48 $\mathrm{hr}$, a further $10 \%$ loss was observed. A significant reduction $(72 \%)$ in tannins and polyphenols of mung bean after 4 days of germination was reported by Noor et al. (1980).

\section{Fermentation}

Fermented foods are essential components of diets in many parts of the world, especially Southeast Asia, because of their higher nutritive value and organoleptic characteristics (Stainkraus and van Veen 1971). The fermentation process improved the bioavailability of essential amino acids and thus improved the nutritional quality of proteins in urd bean. The protein quality of soybean and chickpea was considerably improved by fermentation (Kao and Robinson 1978). These workers further reported that fermentation of these legumes considerably increased the concentration of B group vitamins, niacin and ascorbic acid. Trypsin and chymotrypsin inhibitor activity of cowpea, chickpea, and pigeonpea decreased significantly as a result of fermentation (Zamora and Fields 1979; Rajalakshmi and Vanaja 1967). The decrease in the concentration of oligosaccharides, verbascose and stachyose, noted during $45 \mathrm{hr}$ fermentations of urd bean was a result of their hydrolysis by alphagalactosidase enzymes (Reddy and Salunkhe 1980). In Miso, a soybean fermented product, considerable changes in its chemical composition and nutritional quality are noticed. It was reported that some important vitamins (riboflavin and vitamin B 12) and minerals (calcium) increased whereas phytic acid decreased in miso during fermentation of soybean pastes (Ebine 1986)

\section{Cooking}

Carbohydrates are the principal seed constituents of many grain legumes. The starch digestibility of chickpea, pigeonpea, urd bean and mung bean processed by wet-heat methods is higher than when processed by dry-heat methods (Geervani and Theophilus 1981a). The enhancement of carbohydrate digestibility in cooked legumes is attributed to the swelling and rupturing of starch granules (Jyothi and Reddy 1980). Although cooking improves the nutritional quality of food legumes, prolonged cooking results in a decrease in protein quality and loss of nutrients such as vitamins and minerals. In this context, the soft cooking cultivars of legumes are preferred in order to derive maximum beneficial effect of cooking. A major beneficial effect of cooking of legume grains is the destruction of protease inhibitors which interfere in protein digestibility. The inhibitor activities of soybean, cowpea, lentils, chickpea and pigeonpea were completely destroyed only when subjected to heat under acidic conditions (Sumathai and Pattabiraman 1976). Heat treatment considerably reduced the trypsin inhibitor activity in lentil and pigeonpea, but the effect was more pronounced in lentil. Processing significantly improved the protein quality of legumes and wet-heat methods of processing improved the protein quality to a greater extent than dry-heat methods (Geervani and Theophilus 1981b). A comparison of the effect of roasting and autoclaving on the protein quality of chickpea and mung bean indicated that autoclaving was more beneficial. Trypsin inhibitor of the cowpea was only partially (10-50\%) inactivated by autoclaving and cooking (Elias et al. 1976). Iyengar and Kulkarani (1977) reported that there 
were $60.8,69.4,66.2$ and $72.2 \%$ reductions in oligosaccharides in pigeonpea, chickpea, mung bean and lentil, respectively, as a result of cooking when cooking water was discarded. Amylase inhibitors of chickpea were inactived when extracts were boiled for $10 \mathrm{~min}$. Haemagglutinins are highly sensitive to heat treatment and a complete destruction of their activity is possible in some legumes (Singh, U. 1988).

Considering the effect of heat treatment, a remarkable reduction in some antinutritional factors can be achieved by heating. But excessive heating reduces the nutritive value of legume proteins. Methionine, the most limiting essential amino acid of legumes, has been reported to undergo nutritional damage when heated (Shemer and Perkins 1975). Therefore, it is important to establish the optimum heat conditions to realize the maximum nutritional advantages of cooking of these legume crops.

\section{Future Research NeEdS}

In view of the increasing population growth in developing countries, particularly India and China (the two most populous countries in the world), the present production of grain legumes will have to be increased. Improved productivity, availability and utilization of legumes in the diet of people may help to alleviate the protein-calorie malnutrition problem prevalent in most developing countries. Decortication, or dehulling, of legumes by abrasive milling will remain a major postharvest operation. Although the development of suitable and efficient dehulling methods and machinery would be useful, the identification of cultivars with improved dehulling characteristics must receive increasing attention in the future. An in-depth study on the seed coat microstructure and dehulling properties of legumes would be useful in understanding the factors that influence the quantitative and qualitative losses that occur during dehulling.

Traditional legume foods based on current processing methods have been summarized in this paper. It is apparent that many such traditional foods can be prepared from a variety of legumes. Such processing practices as germination, fermentation, roasting, frying and cooking are legume specific but are becoming increasingly popular. It is essential to describe the optimum conditions for these treatments in order to derive their maximum nutritional effects. Because of their different physicochemical characteristics, processing and utilization technology must be developed for individual legumes. More diversified food uses of these legumes need to be introduced to the villagers and simple technology applicable at home should be developed.

From the point of view of utilization, cooking quality of grain legumes is very important. It may be expected that grain legumes will be utilized more extensively if quick-cooking legume processing technology is adopted on a commercial basis and more acceptable, nutritious and digestible food products are developed. Although there appears to be some variation in the chemical constituents within cultivars of different species, studies should be conducted to determine the effects of locations and environments on these chemical constituents. Also the effects of improved agronomic practices should be more carefully studied, particularly with reference to vitamin and mineral contents.

The chemical analysis does not always reveal how much of a chemical constituent is biologically available. Therefore, detailed studies are needed to establish the biological availability of different nutrients of legumes. More attention should be paid to less-studied legumes such as pigeonpea, lentil and urd bean as far as the bioavailability of different nutrients is concerned.

\section{ACKNowledgment}

This contribution was partly supported by USAID Grant No. DAN 4048-G-SS-2065-OD.

\section{Literature Cited}

Akobundu, E. N. T., and F. H. Hoskins. 1987. Potential of corn-cowpea mixtures as infant food. J. Food Agric. 1:111-114.

Aykroyd, W. R., and J. Doughty. 1964. Legumes in human nutrition. FAO Nutritional Studies No. 19.

Bhatty, R.S. 1988. Composition and quality of lentil (Lens culinaris): a review. Can. Inst. Food Sci. Technol. J. 21:144-160.

Bhumiratana, A. 1978. Mung bean and its utilization in Thailand. Pages $46-48$ in The first international mung bean symposium, Asian Vegetable Research

Chang, C. N. 1978. A study of mung bean sprout products. Pages 64-48 in The first international mung bean symposium, Asian Vegetable Research

Chen, L. H., C. E. Wells, and J. R. Fordham. 1975. Germinated seeds for human consumption. J. Food Sci. 40:1290-1294. 
Collins, J. H., S. M. Kalatari, and A. R. Post. 1982. Peanut hull flour as dietary fiber in wheat bread. J. Food Sci. 47:1899-1902.

Dolvo, E. F., C. E. Williams, and L. Zoaka. 1975. Cowpeas: home preparation and use Africa. International Development Research Centre, IDRC055e, Ottawa.

Ebine, H. 1986. Soybean miso. Pages 47-68 in N. R. Reddy, M. D. Pierson and D. K. Salunkhe, eds., Legume-based fermented foods. CRC Press, Inc., Boca Raton, FL.

Eggum, B. O., and R. M. Beame. 1983. The nutritive value of seed proteins. Pages 499-531 in W. Gottschalk and P. H. Muller, eds., Seed proteins-biochemistry genetics and nutritive value. Junk J.W. Publishers, The Hague.

Ehiwe, A. O. F., and R. D. Reichert. 1987. Variability in dehulling quality of cowpea, pigeonpea, and mung bean cultivars determined with the tangential abrasive dehulling device. Cereal Chem. 64:86-90.

El Hardallou, S. B., A. H. Eltinay, and A. A. M. Nour. 1980. Chemical characteristics of some legumes grown in the Sudan. Sud. J. Food Sci. Tech. 12:3542.

Elias, L. S., F. R. Caistales, R. Bressani, and H. Mirada. 1976. Composicion quimica y valor nutritive de algunas leguminosas de grano. Turrialba 26: 375-386.

Evans, E. R. 1982. Confectionary products from peanuts. Cereal Foods World 27:593-596.

Faris, D. G., K. B. Saxena, S. Mazumdar, and U.Singh. 1987. Vegetable pigeonpea: a promising crop for India. ICRISAT, Patancheru, A.P. India, Pamphlet ICR 87-0022.

Food and Agriculture Organization. 1988. Food and Agriculture Organization production yearbook. Rome, Italy.

Geervani, P., and F. Theophilus. 1981a. Studies on digestibility of selected legume carbohydrates and its impact on the $\mathrm{pH}$ of the gastrointestinal tract in rats. J. Sci. Food Agric. 32:71-78.

, and $-1981 \mathrm{~b}$. Effect of home processing on the protein quality of selected legumes. J. Food Sci. 32:71-78.

Gopalan, C., B. V. Ramasastry, and S. C. Balasubramanian. 1985. Nutritive value of Indian foods, National Institute of Nutrition. Indian Council of Medical Research, Hyderabad, India.

Hawtin, L. 1981. The chick-pea cookbook. The International Center for Agricultural Research in the Dry Areas (ICARDA), Aleppo, Syria.

Hulse, J. H. 1991. Nature, composition, and utilization of grain legumes. Pages 11-27 in The proceedings of the consultants' meeting on uses of tropical grain legumes, 27-30 Mar 1989, ICRISAT Centre, Patancheru, A. P. 502 324, India.

Iyengar, A. K., and P. R. Kulkarani. 1977. Oligosac- charide levels of processed legumes. J. Food Szi. Technol. 14:222-224.

Jambunathan, R., and U.Singh. 1990. Present status and prospects for utilization of chickpea. Pages 4148 in Chickpea in the nineties: Proceedings of the second international workshop on chickpea improvement, 4-8 Dec 1989, ICRISAT Center, Patancheru, Andhra Pradesh 502 324, India.

Jyothi, E., and P. R. Reddy. 1980. Effect of germination and cooking on the in vitro digestibility of starch in some legumes. Nutr. Rep. International 23:799-804.

Kao, C., and R. J. Robinson. 1978. Nutritional aspects of fermented foods from chickpea, horse bean, and soybean. Cereal Chem. 55:512-517.

Khaleque, A., L. G. Elias, J. E. Braham, and R. Bressani. 1985. Studies on the development of infant foods from plant protein sources. 1. Effect of germination of chickpea on the nutritive value and digestibility of proteins. Arch. Latinoamer. Nutr. 35:315-325.

Khan, M. A. 1987. Nutritional attributes of food legumes. Progressive Farming (Pakistan) 7:36-40.

- I. A. Rana, I. Ullah, and S. Jaffery. 1987. Physicochemical characters and nutrient composition of some improved lines of lentils grown in Pakistan. J. Food Comp. Anal. 1:65-70.

Kylen, A. M., and R. M. McCready. 1975. Nutrients in seeds and sprouts of alfalfa, lentils, mungbeans and soybeans. J. Food Sci. 40:1008-1009.

Lusas, E. W. 1979. Food uses of peanut protein. J. Amer. Oil Chem. Soc. 56:425-430.

Liener, I. E. 1979. Significance for humans of biologically active factors in soybeans and other food legumes. J. Amer. Oil. Chem. Soc. 56:121-128.

National Academy of Science. 1975. Population and food-crucial issues. National Academy of Science, Washington, D.C.

Ngarmsak, T. 1989. Development of cowpea products for utilization in the villages of North Eastern Thailand. Paper presented at consultants' meeting on uses of grain legumes, ICRISAT, Patancheru, A. P. India.

Noor, M. L., R. Bressani, and L. G. Elias. 1980. Changes in chemical and selected biochemical components, protein quality, and digestibility of mung bean (Vigna radiata) during germination and cooking. Qual. Plant. Plant Foods Hum. Nutr. 30:135144.

Olson, R. E. 1975. Protein-calorie nutrition. Academic Press, New York.

Ory, R. L., and E. J. Conkerton. 1983. Supplementation to bakery items with high protein peanut flour. J. Amer. Oil Chem. Soc. 60:986-989.

Payumo, E. M. 1978. The potentials of mung bean as a protein supplement for child feeding. Pages 40 45 in The first international mung bean sympo- 
sium, Asian Vegetable Research and Development Center, Taiwan.

Rachie, K. O., and L. M. Roberts. 1974. Grain legumes of the lowland tropics. Advances Agron. 26: 72-77.

Rajalakshmi, R., and K. Vanaja. 1967. Chemical and biological evaluation of the effects of fermentation on the nutritive value of foods prepared from rice and Bengal gram. Brit. J. Nutr. 21:467-473.

Rao, D. S., and Y. G. Deosthale. 1981. Mineral composition of four Indian food legumes. J. Food Sci. 46:1962-1963.

Rao, P. U., and B. Belavady. 1978. Oligosaccharides in pulses: varietal differences and effects of cooking and germination. J. Agric. Food Chem. 26:316319.

- and Y. G. Deosthale. 1982. Tannin content of pulses: varietal differences and effect of cooking and germination. J. Sci. Food Agric. 33:1013-1016.

Reber, E. F., L. Eboh, A. Aladeselu, W. A. Brown, and D. D. Marshall. 1983. Development of high-protein low cost Nigerian foods. J. Food Sci. 48:217219.

Reddy, N. R., and D. K. Salunkhe. 1980. Changes in oligosaccharides during germination and cooking of black gram and fermentation of black gram and rice blends. Cereal Chem. 57:356-360.

Saio, K., and T. Watanabe. 1984. Advanced food technology of soybean and other legumes in Japan. In Tropical agriculture research services No. 6. Tropical Agriculture Research Center, Tokyo, Japan.

Salunkhe, D. K. 1982. Legumes in human nutrition. Current status and future research needs. Current Sci. 51:387-394.

Savitri, A., and H. S. R. Desikachar. 1985. A comparative study of flatus production in relation to the oligosaccharides content of some legumes. Nutr. Rep. International 31:337-344.

Shemer, M., and E. G. Perkins. 1975. Degradation of methionine in heated soybean protein and the formation of Beta-methyl mercaptopropionaldehyde. J. Agric. Food Chem. 23:201-205.

Shobhana, S. P. S., H. S. Nainawatee, and B. M. Lal. 1976. Chemical composition of some improved varieties of pulses. J. Food Sci. Technol. 13:49-51.

Siegel, A., and B. Fawcett. 1976. Food legume processing and utilization. The IDRC technical studies report TSI.

Singh, B. 1986. An interdisciplinary approach to optimum food utility of peanut in SAT Africa. Annual Report Peanut CRSP. University of Georgia, Griffin.

- 1991. Cereal-based foods using groundnuts and other legumes. Pages 293-301 in The proceedings of the consultants' meeting on uses of tropical grain legumes, 27-30 Mar 1989, ICRISAT Centre, Patancheru, Andhra Pradesh 502 324, India. and U. Singh. 1991. Peanut as a source of protein for human foods. Plant Foods for Human Nutr. 41:165-177.

Singh, R. B. 1984. Trends and prospects of grain legume production in Asia and Pacific. Pages 7679 in Legumes in Asia. International Crops Research Institute for the Semi-Arid Tropics, Patancheru, India.

Singh, U. 1985. Nutritional quality of chick-pea ( $\mathrm{C} i$ cer arietinum $\mathrm{L}$.): current status and future research needs. Qual. Plant. Plant Foods Hum. Nutr. 35: 339-351.

- 1987. Cooking quality of some important Indian grain legumes. In National symposium on present status and future perspectives in technology of food grains. Central Food Technological Research Institute, (CFTRI), Mysore, India

- 1988. Antinutritional factors of chickpea and pigeonpea and their removal by processing. Qual. Plant. Plant Foods Hum. Nutr. 28:251-256.

- and R. Jambunathan. 1981. A survey of methods of milling and consumer acceptance of pigeonpea in India. Pages 419-425 in International workshop on pigeonpea, vol. 2,15-19 Dec 1980, International Crops Research Institute for the SemiArid Tropics, Patancheru, A. P. India.

- and - 1991. Pulses as a substitute for animal protein. Pages 191-197 in The proceedings of advances in pulses research in Bangladesh, national workshop on pulses, 6-8 June 1989, Joydebput, Bangladesh, Bangladesh Agricultural Research Institute (BARI), Bangladesh

, P. V. Rao, R. Seetha, and R. Jambunathan. 1989. Nutrient losses due to saccharification of pigeonpea (Cajanus cajan L.) cotyledons. J. Food Sci. 54:974-981.

-, M. Voraputhaporn, P. V. Rao, and R. Jambunathan. 1989. Physicochemical characteristics of pigeonpea and mung bean starches and their noodle quality. J. Food Sci. 54:1293-1297.

Soni, G. L., M. George, and R. Singh. 1982. Role of common Indian pulses as hypocholesterolemic agents. Ind. J. Nutr. and Diet. 19:184-190.

Stainkraus, K. H., and A. G. van Veen. 1971. Biochemical, nutritional and organoleptic changes occurring during production of traditional fermented foods. Pages 144-160 in Y. M. Freitas and F. Fernandez, eds., Global impacts of applied microbiology. IBP-UNESCO, Geneva.

Sumathai, S., and T. N. Pattabiraman. 1976. Natural plant enzyme inhibitors: part II-protease inhibitors of seeds. Ind. J. Biochem. Biophys. 13:52-56.

Tylor, R. T., C. G. Youngs, and F. W. Sosulski. 1981. Air classification of legumes. 1. Separation efficiency, yield, and composition of the starch and protein fractions. Cereal Chem. 58:144-152.

Williams, P. C., and U. Singh. 1988. Quality screening and evaluation in pulse breeding. Pages 445- 
456 in R. J. Summerfield, ed., World crops: cool season food legumes. Kluwer Academic Publishers, London.

Wilson, K. A., and A. L. Tan-Wilson. 1983. Proteinases involved in degradation of trypsin inhibitor in germinating mungbean. Acta Biochim. Polon. 30: 139-143.

Zamora, A. F., and M. L. Fields. 1979. Nutritive quality of fermented cowpeas and chickpeas. J. Food Sci. 44:234-236. 